\title{
Pengaruh Media Pembelajaran Berbasis Web terhadap Keterampilan Berpikir Kritis dan Kemampuan Kognitif
}

\author{
Idi Rathomy Baisa ${ }^{1}$ \\ 1Pendidikan Biologi-Universitas Negeri Malang
}

INFO ARTIKEL

Riwayat Artikel:

Diterima: 21 Juni 2018

Disetujui: 16 Oktober 2018

\section{Kata kunci:}

Media pembelajaran

Berpikir kritis

Eksperimen semu

Kemampuan kognitif

\begin{abstract}
ABSTRAK
Abstract: This research is done in order to influence of the application of web-based learning media to the critical thinking. The influence of the application of web-based learning media to cognitive ability. Research design used is quasi experimental research with the design of Pretestposttest Nonequivalent Control Group. The research result of the influence of the application of web-based learning media to the critical thinking and academic ability can influence in the application of web-based learning media to the critical thinking. There is an influence in the application of web-based learning media to cognitive ability. Further examination shows that the application of learning media has $14,33 \%$ higher score than the application of Student's Activity Sheet.
\end{abstract}

\begin{abstract}
Abstrak: Penelitian ini dilakukan untuk mengetahui pengaruh penerapan media pembelajaran berbasis web terhadap keterampilan berpikir kritis. Pengaruh penerapan media pembelajaran berbasis web terhadap kemampuan kognitif. Rancangan penelitian yang digunakan adalah penelitian eksperimen semu (quasi experiment) dengan rancangan Pretestposttest Nonequivalent Control Group. Hasil penelitian menunjukkan adanya pengaruh penerapan media pembelajaran berbasis web terhadap keterampilan berpikir kritis dan adanya pengaruh penerapan media pembelajaran berbasis web terhadap kemampuan kognitif. Hasil uji lanjut menunjukkan bahwa penerapan media pembelajaran berbasis web memiliki nilai 14,33\% lebih tinggi dibandingkan dengan penerapan Lembar Kegiatan Siswa.
\end{abstract}

\author{
Alamat Korespondensi: \\ Idi Rathomy Baisa \\ Pendidikan Biologi \\ Pascasarjana Universitas Negeri Malang \\ Jalan Semarang 5, Malang 65145 \\ E-mail: idir.baisa@gmail.com
}

Media pembelajaran berbasis teknologi khususnya komputer sudah berkembang pesat. Media pembelajaran interaktif berbasis komputer banyak dijual dalam bentuk CD (Compact Disk) yang memanfaatkan program Macromedia Flash. Media pembelajaran tersebut bersifat interaktif dan menarik tetapi materi yang disajikan terkadang kurang sesuai dengan harapan siswa atau guru. Salah satu alternatif adalah media pembelajaran berbasis web yang dibuat sendiri oleh guru. Media pembelajaran berbasis web memungkinkan banyak link antar materi pelajaran sehingga menjadikan media tersebut lebih bervariasi. Dalam beberapa penelitian seperti yang telah dilakukan oleh (Kuswana, 2009) hasilnya adalah pengembangan media pembelajaran berbasis web dari segi keefektifan proses belajar menunjukkan adanya kecenderungan siswa termotivasi untuk membelajarkan diri secara otonomi.

Hasil belajar saja belum cukup untuk membekali siswa karena masih dibutuhkan keterampilan proses seperti keterampilan berpikir kritis. Kemampuan seseorang agar dapat berhasil dalam kehidupan, salah satunya ditentukan oleh keterampilan berpikir, terutama dalam upaya memecahkan masalah-masalah dalam kehidupan yang dihadapinya. Untuk itulah diperlukan inovasi penyediaan sarana belajar bagi siswa agar dapat meningkatkan keterampilan berpikir kritis dan kemampuan kognitif. Salah satu media pembelajaran 
yang mungkin dapat memfasilitasi dalam mengembangkan keterampilan berpikir kritis dan kemampuan kognitif adalah media pembelajaran berbasis web yang perlu diteliti pengaruhnya.

Penelitian ini bertujuan untuk mengetahui pengaruh media pembelajaran berbasis web terhadap keterampilan berpikir kritis dan kemampuan kognitif pada siswa yang berkemampuan akademik tinggi maupun siswa yang berkemampuan akademik rendah. Hasil penelitian ini diharapkan dapat memberikan inspirasi bagi guru dalam meningkatkan kualitas pendidikan khususnya peningkatan keterampilan berpikir kritis yang pada akhirnya akan berdampak pada peningkatan prestasi belajar siwa.

\section{METODE}

Rancangan penelitian yang digunakan adalah penelitian eksperimen semu (quasi experiment) dengan rancangan Pretest-posttest Nonequivalent Control Group. Penelitian ini mengungkap hubungan sebab akibat antara variabel bebas penerapan media pembelajaran berbasis web dengan Lembar Kegiatan Siswa terhadap variabel terikat yaitu keterampilan berpikir kritis dan kemampuan kognitif. Variabel moderatornya adalah kemampuan akademik tinggi dan kemampuan akademik rendah. Sampel penelitian ini adalah siswa kelas VA dan VD yang ditentukan secara acak dari populasi 120 siswa yang terbagi dalam 4 kelas paralel.

Instrumen penelitian yang digunakan adalah tes keterampilan berpikir kritis untuk mengukur 8 keterampilan berpikir kritis (Hadi, 2007) dan tes kemampuan kognitif yang mengacu pada taksonomi bloom yang disempurnakan oleh (Krathwohl, 2002). Pengumpulan data dilakukan oleh peneliti berupa data hasil pretes dan postes untuk kelas eksperimen dan kelas kontrol. Pengumpulan data tersebut juga dilakukan dengan cara mengamati performansi siswa dalam proses pembelajaran di dalam kelas. Analisis data yang digunakan ada dua yaitu teknik statistik deskriptif dan teknik statistik inferensial parametrik. Teknik analisis statistik deskriptif digunakan untuk mendeskripsikan data dalam bentuk tabel dan grafik. Teknik statistik inferensial parametrik digunakan untuk menguji hipotesis. Statistik yang digunakan adalah Anacova (Analysis of Covariance).

\section{HASIL}

\section{Pengaruh Penerapan Media Pembelajaran Berbasis Web terhadap Keterampilam Berpikir Kritis}

Hasil penelitian secara deskriptif menunjukkan bahwa siswa yang belajar dengan menggunakan media pembelajaran berbasis web mengalami kenaikan nilai rerata keterampilan berpikir kritis dan nilainya berada pada kategori baik sekali $(86$ - 100). Berdasarkan hasil analisis data statistik pada pengaruh penerapan media pembelajaran berbasis web terhadap keterampilan berpikir kritis menunjukkan nilai $\mathrm{F}$ hitung yang lebih kecil daripada a yang berarti bahwa hipotesis penelitian ini diterima yaitu ada pengaruh penerapan media pembelajaran berbasis web terhadap keterampilan berpikir kritis. Hasil uji lanjut menunjukkan bahwa penerapan media pembelajaran berbasis web memiliki nilai 20,3\% lebih tinggi dibandingkan dengan penerapan Lembar Kegiatan Siswa.

\section{Pengaruh Penerapan Media Pembelajaran Berbasis Web terhadap Kemampuan Kognitif}

Penerapan media pembelajaran berbasis web dapat meningkatkan kemampuan kognitif siswa dengan rerata nilai dalam kategori baik sekali $(86$ - 100) untuk siswa berkemampuan akademik tinggi dan kategori baik $(71-85)$ untuk siswa berkemampuan akademik rendah. Berdasarkan hasil analisis data statistik pada pengaruh penerapan media pembelajaran berbasis web terhadap kemampuan kognitif siswa menunjukkan nilai $\mathrm{F}$ hitung lebih kecil daripada a yang berarti bahwa hipotesis penelitian ini diterima yaitu ada pengaruh penerapan media pembelajaran berbasis web terhadap kemampuan kognitif. Hasil uji lanjut menunjukkan bahwa penerapan media pembelajaran berbasis web memiliki nilai 14,33\% lebih tinggi dibandingkan dengan penerapan Lembar Kegiatan Siswa.

\section{Pengaruh Kemampuan Akademik Terhadap Keterampilan Berpikir Kritis}

Berdasarkan hasil analisis statistik pada pengaruh kemampuan akademik dan interaksinya terhadap keterampilan berpikir kritis menunjukkan nilai $\mathrm{F}$ hitung lebih kecil daripada nilai a yang berarti bahwa hipotesis penelitian ini diterima yaitu ada pengaruh kemampuan akademik terhadap keterampilan berpikir kritis. Hasil uji lanjut juga menunjukkan bahwa kemampuan akademik tinggi memiliki nilai 20,3\% lebih tinggi dibandingkan dengan kemampuan akademik rendah. Hasil uji lanjut tersebut menunjukkan bahwa siswa yang memiliki kemampuan akademik tinggi lebih baik daripada siswa berkemampuan akademik rendah dalam berpikir kritis. 


\section{Pengaruh Kemampuan Akademik Terhadap Kemampuan Kognitif}

Berdasarkan hasil analisis statistik pada pengaruh kemampuan akademik dan interaksinya terhadap kemampuan kognitif menunjukkan nilai $\mathrm{F}$ hitung lebih kecil daripada nilai a yang berarti bahwa hipotesis penelitian ini diterima yaitu ada pengaruh kemampuan akademik terhadap kemampuan kognitif. Hasil uji lanjut juga menunjukkan bahwa kemampuan akademik tinggi memiliki nilai 7,33\% lebih tinggi dibandingkan dengan kemampuan akademik rendah. Hasil uji lanjut tersebut menunjukkan bahwa siswa berkemampuan akademik tinggi lebih baik daripada siswa berkemampuan akademik rendah dalam hal kemampuan kognitifnya.

\section{Pengaruh Interaksi Antara Penerapan Media Pembelajaran Berbasis Web dengan Kemampuan Akademik terhadap Keterampilan Berpikir Kritis}

Hasil uji statistik interaksi antara penerapan media pembelajaran berbasis web dengan kemampuan akademik menunjukkan nilai $\mathrm{F}$ hitung yang lebih besar daripada nilai a yang berarti bahwa tidak ada pengaruh interaksi antara penerapan media pembelajaran berbasis web dengan kemampuan akademik terhadap keterampilan berpikir kritis. Tidak adanya pengaruh interakasi tersebut berarti bahwa tidak ada perbedaan keterampilan berpikir kritis siswa yang berkemampuan akademik tinggi maupun siswa yang berkemampuan akademik rendah karena nilainya dalam kategori baik sekali.

\section{Pengaruh Interaksi Antara Penerapan Media Pembelajaran Berbasis Web dengan Kemampuan Akademik terhadap Kemampuan Kognitif}

Hasil uji statistik pengaruh interaksi antara penerapan media pembelajaran berbasis web dengan kemampuan akademik terhadap kemampuan kognitif menunjukkan nilai $\mathrm{F}$ hitung lebih besar daripada nilai $\alpha$ yang bearti bahwa tidak ada pengaruh interaksi antara penerapan media pembelajaran berbasis web dan kemampuan akademik terhadap kemampuan kognitif. Penolakan hipotesis tersebut berarti bahwa tidak ada perbedaan kemampuan kognitif siswa yang berkemampuan akademik tinggi maupun siswa yang berkemampuan akademik rendah karena nilainya dalam kategori baik sekali dan baik.

\section{Persepsi Siswa Kelas V SD Islam Sabilillah Malang terhadap Penerapan Media Pembelajaran Berbasis Web}

Berdasarkan analisis angket, secara umum siswa kelas V SD Islam Sabilillah Malang merasa senang ketika mengikuti kegiatan pembelajaran dengan menggunakan media pembelajaran berbasis web. Hasil analisis data angket persepsi siswa terhadap penerapan media pembelajaran berbasis web secara umum, 85\% merasa mudah dalam mengoperasikan media pembelajaran berbasis web,78,35\% siswa merasa tertarik dalam menggunakan media pembelajaran berbasis web, dan 73,35\% siswa merasa senang (enjoy) dalam mengikuti kegiatan pembelajaran dengan menggunakan media pembelajaran berbasis web.

\section{PEMBAHASAN}

\section{Pengaruh Penerapan Media Pembelajaran Berbasis Web terhadap Keterampilan Berpikir Kritis}

Pengaruh penerapan media pembelajaran berbasis web lebih baik daripada penerapan Lembar Kegiatan Siswa (LKS) karena media pembelajaran berbasis web memang memiliki banyak keunggulan. Keunggulan media pembelajaran berbasis web antara lain siswa mendapatkan banyak materi selain yang ada di dalam buku paket. Mereka dapat berinteraksi langsung dengan media pembelajaran dan juga dengan kelompoknya. Interaksi yang multiarah tersebut memungkinkan siswa dapat berpikir kritis dalam menghadapi suatu permasalahan yang dihadapinya. Menurut (Mustafa, 2005), media pembelajaran berbasis web memungkinkan bagi guru untuk menciptakan pembelajaran yang berpusat pada siswa, kolaboratif, dan pembelajaran kontekstual sehingga siswa terlibat dalam pemikiran kritis dan pemecahan masalah.

Media pembelajaran berbasis web diterapkan dalam bentuk kelompok kecil (satu komputer untuk dua siswa). Melalui kegiatan bersama dalam kelompok kecil memungkinkan siswa dapat bebas berinteraksi, bertukar pikiran dan memecahkan masalah bersama-sama sehingga terbentuk kemampuan berpikir tingkat tinggi. Hal ini senada dengan ungkapan Gokhale (Sudaryanto, 2008) yang menyatakan bahwa pembelajaran kolaboratif melalui diskusi kelompok kecil direkomendasikan sebagai strategi yang dapat meningkatkan kemampuan berpikir kritis. 
Hasil penelitian (Lieberman \& Pointer Mace, 2010) dalam Journal of Teacher Education menyatakan bahwa pembelajaran kolaboratif berbasis web dapat memudahkan interaksi kelas, meningkatkan kekompakan kelompok, dan menciptakan suasana kompetitif yang positif sehingga dapat merangsang siswa berpikir kreatif. Dengan berdiskusi, siswa akan memperoleh banyak kesempatan untuk mengklarifikasi pemahamannya dan mengevaluasi pemahaman siswa yang lain, mengobservasi strategi berpikir dari orang lain untuk dijadikan panutan, membantu siswa lain yang masih kurang untuk membangun pemahaman, meningkatkan motivasi, serta membentuk sikap yang diperlukan seperti menerima kritik dan menyampaikan kritik dengan cara yang santun.

Media pembelajaran berbasis komputer mempunyai peranan penting dalam meningkatkan kemampuan siswa dalam memecahkan berbagai masalah. (Wong \& Trinidad, 2004) menyatakan bahwa pemanfaatan komputer sebagai media pembelajaran dapat membantu siswa bekerja secara efektif melalui pembelajaran tingkat tinggi yang berorientasi pada pemecahan masalah. Mereka dapat memanfaatkan sumber belajar di komputer sebanyak mungkin sehingga mereka dapat memecahkan masalah dengan baik. Media pembelajaran berbasis komputer dapat memberikan berbagai informasi dalam lingkup yang lebih luas dan mendalam sehingga meningkatkan wawasan siswa. Hal ini merupakan rangsangan yang kondusif bagi berkembangnya kemandirian anak terutama dalam hal pengembangan kompetensi, kreativitas, pengendalian diri, konsistensi, dan komitmennya baik terhadap diri sendiri maupun terhadap pihak lain.

\section{Pengaruh Penerapan Media Pembelajaran Berbasis Web terhadap Kemampuan Kognitif}

Pengaruh penerapan media pembelajaran berbasis web lebih baik daripada penerapan Lembar Kegiatan Siswa (LKS) karena media pembelajaran berbasis web memang memiliki banyak keunggulan terutama dalam hal melatih kemampuan kognitif. Keunggulan media pembelajaran berbasis web antara lain adalah adanya berbagai macam bentuk latihan soal interaktif. Melalui media tersebut, siswa mempunyai kesempatan yang banyak untuk berlatih dengan cara mengerjakan berbagai macam bentuk latihan soal interaktif. Setiap kali siswa selesai mengerjakan soal, mereka dapat langsung melihat hasilnya. Siswa juga dapat mengetahui jawaban yang benar dan ada bimbingan apabila siswa mengalami kesalahan dalam mengerjakan soal. Latihan soal tersebut dapat dikerjakan siswa berulangkali sampai mereka faham. Latihan soal secara berulang tersebut memungkinkan siswa dapat melatih kemampuan kognitifnya.

Hasil penelitian ini senada dengan penelitian yang dilakukan (Sudaryanto, 2008) yang menyatakan bahwa pembelajaran menggunakan media komputer lebih berpengaruh terhadap kemampuan kognitif siswa dari pada pembelajaran berbasis Lembar Kegiatan Siswa. Lembar Kegiatan Siswa (LKS) hanya berisi sedikit materi yang disertai dengan latihan soal atau arahan dalam pembahasan materi. Tampilan media pembelajaran dalam komputer lebih menarik daripada berupa lembaran LKS.

Sebagai data pelengkap, hasil analisis angket menunjukkan bahwa siswa yang diajar menggunakan media pembelajaran berbasis web menunjukkan bahwa 78,35\% siswa merasa tertarik dengan media pembelajaran berbasis web, merasa penasaran dan ingin mengulang belajar menggunakan media pembelajaran berbasis web. Ketertarikan siswa dan rasa senang siswa dalam menggunakan media pembelajaran berbasis web memungkinkan mereka sering membaca dan berlatih sehingga kemampuan kognitifnya juga meningkat.

Siswa merasa senang dan mudah dalam menggunakan media pembelajaran berbantuan komputer. Hasil penelitian ini senada dengan ungkapan (Gora, 2005) bahwa bersekolah menjadi lebih mudah dan menyenangkan karena hanya dengan beberapa kali klik (istilah komputer ketika menekan mouse komputer) semua proses belajar mengajar dapat diselesaikan dengan cepat dan siswa merasa tidak tertekan.

\section{Pengaruh Kemampuan Akademik terhadap Keterampilan Berpikir Kritis}

Kemampuan akademik merupakan salah satu faktor yang berpengaruh terhadap hasil belajar siswa. Siswa yang memiliki kemampuan akademik tinggi ada kecenderungan lebih baik dalam hal kosentrasi belajar, proaktif dalam kegiatan diskusi, dan memiliki motivasi yang tinggi dalam belajar dan berprestasi. Temuan ini didukung peneliti lain seperti (Hadi, 2009) yang menyatakan bahwa siswa dengan kemampuan akademik tinggi memiliki pemahaman konsep yang lebih tinggi daripada siswa yang memiliki kemampuan akademik rendah. Pemahaman konsep yang tinggi tersebut dapat memicu siswa untuk berpikir lebih kritis.

(Nurmaliah, 2009) menyatakan bahwa kemampuan awal merupakan salah satu faktor yang mempengaruhi kemampuan berpikir. Siswa yang berkemampuan awal tinggi penalarannya juga tinggi. Daya nalar yang 
tinggi tersebut akan mendorong siswa untuk berpikir kritis sehingga kemampuan awal dan daya nalar yang tinggi dapat mempengaruhi kemampuan berpikir siswa.

\section{Pengaruh Kemampuan Akademik terhadap Kemampuan Kognitif}

Siswa yang memiliki kemampuan akademik tinggi ada kecenderungan lebih baik dalam hal hasil belajarnya. Mereka sudah memiliki modal dasar kemampuan kognitif yang baik, sehingga dengan dukungan media pembelajaran yang baik maka kemampuan akademiknya juga akan meningkat lebih baik lagi. Siswa yang memiliki kemampuan akademik tinggi akan memiliki daya nalar yang baik dan mampu mengorganisasi materi pelajaran sehingga mereka mudah memahami pelajaran dan hasil belajarnya lebih baik. Siswa yang memiliki kemampuan akademik tinggi juga memiliki gaya belajar yang efektif dan lebih baik dalam menjaga kosentrasi belajarnya sehingga kemampuan kognitifnya akan lebih baik.

(Suparno, 2001) mengemukakan bahwa menurut teori konstruktivisme Piaget, pengetahuan adalah bentukan orang itu sendiri. Proses pembentukan pengetahuan terjadi apabila seseorang mengubah atau mengembangkan skema yang telah dimiliki seseorang dalam menghadapi tantangan, rangsangan, atau persoalan. Pembentukan pengetahuan ditentukan oleh kegiatan atau keaktifan seseorang yang erat kaitannya dengan kemampuan akademik siswa. Siswa yang memiliki kemampuan akademik tinggi dapat mengkonstruksi pengetahuannya dengan baik sehingga akan berdampak pada peningkatan kemampuan kognitifnya.

\section{Pengaruh Interaksi Antara Penerapan Media Pembelajaran Berbasis Web dengan Kemampuan Akademik terhadap Keterampilan Berpikir Kritis}

Berdasarkan hasil analisis data ditemukan bahwa tidak ada interaksi antara penerapan media pembelajaran berbasis web dengan kemampuan akademik terhadap peningkatan keterampilan berpikir kritis. Secara terpisah, penerapan media pembelajaran berbasis web dapat meningkatkan keterampilan berpikir kritis siswa dan kemampuan akademik juga dapat mempengaruhi peningkatan keterampilan berpikir kritis. Hasil penelitian ini senada dengan hasil penelitian (Winarni, 2006) yang menyatakan bahwa tidak ada pengaruh interaksi antara strategi pembelajaran dan tingkat kemampuan akademik terhadap kemampuan berpikir kritis. Strategi pembelajaran yang baik (termasuk didalamnya penggunaan media pembelajaran) akan memberikan dampak positif bagi peningkatan hasil belajar siswa tanpa melihat latar belakang kemampuan awal siswa.

Hasil penelitian yang menyatakan tidak ada pengaruh interaksi penerapan media pembelajaran berbasis web dan kemampuan akademik terhadap keterampilan berpikir kritis berarti bahwa tidak ada perbedaan keterampilan berpikir kritis siswa yang berkemampuan akademik tinggi maupun siswa yang berkemampuan akademik rendah. Hasil penelitian menunjukkan bahwa nilai keterampilan berpikir kritis siswa berkemampuan akademik tinggi dan siswa berkemampuan akademik rendah yang diajar dengan menggunakan penerapan media pembelajaran berbasis web keduanya termasuk dalam kategori baik sekali. Rerata nilai postes dari keterampilan berpikir kritis pada siswa berkemampuan akademik tinggi adalah 93,45 dan siswa berkemampuan akademik rendah adalah 87,78. Perolehan nilai tersebut membuktikan bahwa media pembelajaran berbasis web memberikan dampak yang positif terhadap keterampilan berpikir kritis pada siswa berkemampuan akademik tinggi maupun siswa berkemampuan akademik rendah.

Penerapan media pembelajaran berbasis web dapat meningkatkan keterampilan berpikir kritis karena media pembelajaran tersebut memiliki banyak kelebihan dibandingkan dengan media pembelajaran lain (selain media berbasis komputer). Keungulan media pembelajaran berbasis web tersebut antara lain adalah pembelajaran lebih berorientasi pada siswa (siswa lebih banyak aktif). Siswa memiliki peluang untuk belajar tentang masalah yang sulit secara berulang kali sampai pemahamannya tercapai. Mereka dapat belajar di dalam suasana yang "aman" tanpa merasa malu untuk bertanya. Pembelajaran dilakukan secara kelompok kecil sehingga siswa dapat selalu berinteraksi dengan temannya. Diskusi dalam kelompok kecil tersebut dapat meningkatkan kemampuan berkomunikasi yang sekaligus dapat meningkatkan keterampilan berpikir siswa. Sumber belajar bervariasi dari segi materi maupun cara penyajiannya. Materi pelajaran yang diperoleh siswa dalam media pembelajaran berbasis web cukup bervariasi dan dilengkapi dengan ilustrasi sehingga dapat meningkatkan keterampilan berpikir siswa.

Keterampilan berpikir kritis dapat ditingkatkan karena penerapan media pembelajaran berbasis web tersebut dirancang dan diterapkan secara menyenangkan. Mereka bebas belajar dan mengeksploitasi 
pengetahuan dari media pembelajaran tersebut. (Khosrow-Pour, 2001) menyatakan bahwa media pembelajaran berbasis web dapat meningkatkan hasil belajar dan cocok untuk belajar jika diterapkan secara efektif.

(Febriyanti, 2007) dalam penelitiannya menyimpulkan bahwa pemanfaatan komputer dilihat dari segi dampak psikologis yang ditimbulkan, interaksi dalam kegiatan belajar siswa, dan bantuan komputer dalam keterampilan belajar siswa sangat efektif dalam menunjang pembelajaran IPA. Penerapan media pembelajaran berbasis komputer yang dilakukan secara bersama-sama dalam kelompok kecil memungkinkan adanya multiinteraksi yaitu interaksi antara siswa dengan sumber belajar dan siswa dengan siswa yang lainnya.

\section{Pengaruh Interaksi Antara Penerapan Media Pembelajaran Berbasis Web dengan Kemampuan Akademik terhadap Kemampuan Kognitif}

Hasil penelitian yang menyatakan tidak ada pengaruh interaksi penerapan media pembelajaran berbasis web dan kemampuan akademik terhadap kemampuan kognitif berarti bahwa tidak ada perbedaan kemampuan kognitif siswa yang berkemampuan akademik tinggi maupun siswa yang berkemampuan akademik rendah. Hasil penelitian menunjukkan bahwa nilai kemampuan kognitif siswa berkemampuan akademik tinggi termasuk dalam kategori baik sekali (86 - 100) dan siswa berkemampuan akademik rendah termasuk dalam kategori baik (71 - 85).

Peningkatan kemampuan kognitif siswa yang berkemampuan akademik tinggi dan berkemampuan akademik rendah diduga salah satunya karena media pembelajaran berbasis web memiliki beberapa keunggulan antara lain, media pembelajaran berbasis web tersebut dirancang sesuai dengan kondisi siswa sehingga mudah dioperasikan oleh siswa berkemampuan akademik tinggi maupun siswa berkemampuan akademik rendah. Media pembelajaran tersebut sesuai dengan kebutuhan siswa karena dirancang sendiri oleh guru berdasarkan indikator pembelajaran dan kemampuan siswa. Kesesuaian materi tersebut memungkinkan tercapainya kompetensi dasar yang diharapkan dan berimbas pada peningkatan hasil belajar siswa. Media pembelajaran berbasis web mengarah pada pembelajaran bermakna. Kegiatan pembelajaran dengan menggunakan media pembelajaran berbasis web memungkinkan siswa: (1) aktif dalam belajar, (2) aktif mengakomodasikan ide-ide, dan (3) siswa bekerja dalam kelompok. Ketiga aktifitas siswa tersebut merupakan ciri dari pembelajaran bermakna (Henry, 2006).

Media pembelajaran berbasis web memungkinkan siswa belajar dengan senang. Menu dalam media pembelajaran bervariasi dengan tampilan yang menarik sehingga menimbulkan rasa senang siswa. Media pembelajaran berbasis web terbukti dapat menimbulkan rasa senang bagi siswa. Berdasarkan data deskriptif hasil pengamatan performansi, siswa terlihat aktif, semangat, dan serius secara bersama-sama dalam menggunakan media pembelajaran berbasis web. Keseriusan, semangat, aktivitas dan kerjasama ketika menggunakan media pembelajaran berbasis web memungkinkan semua siswa dapat mengerjakan soal tes dengan baik. Penerapan media pembelajaran berbasis web ini memberikan kesempatan yang luas bagi siswa yang memiliki kemampuan akademik rendah agar dapat berinteraksi dengan teman yang lain, sehingga mereka dapat bekerjasama secara kooperatif mencapai hasil yang lebih baik.

Keunggulan media pembelajaran berbasis web lain ada adalah adanya kemampuan untuk meningkatkan motivasi belajar. (Wong \& Trinidad, 2004) menyatakan bahwa belajar dengan menggunakan media pembelajaran berbasis web (Web Based Teaching) memungkinkan siswa belajar dengan rasa senang dan dalam kelompok kolaboratif. Motivasi belajar siswa ketika menggunakan komputer akan meningkat sebagaimana dinyatakan oleh (Arends, 2012) bahwa kenyatan menunjukkan belajar/ bekerja dengan komputer merupakan motivasi terbaik.

Media pembelajaran berbasis komputer terbukti dapat meningkatkan hasil belajar siswa berkemampuan akademik tinggi maupun siswa yang berkemampuan akademik rendah. (Dabutar, 2007) menyatakan bahwa penggunaan media pembelajaran berbantuan komputer memberi pengaruh sangat signifikan terhadap perolehan hasil belajar siswa yang berprestasi rendah. Peningkatan hasil belajar siswa berkemampuan akademik rendah tersebut merupakan dampak dari keunggulan yang dimiliki oleh media pembelajaran berbasis komputer.

Tampilan media pembelajaran berbasis web yang dirancang dalam penelitian ini disajikan secara sistematis, menarik dan dapat menimbulkan motivasi belajar bagi siswa. Menu media pembelajaran berbasis web antara lain: (1) menu utama (halaman depan), (2) menu belajar yang menyajikan kumpulan bahan ajar, (3) menu latihan 
soal yang berisi berbagai macam bentuk latihan soal interaktif, dan (4) menu aku tahu yang berisi pengetahuan tambahan terkait dengan konsep yang dipelajari.

Materi dalam media pembelajaran berbasis web dirancancang oleh guru dari berbagai sumber belajar seperti buku dan internet. Materi pelajaran dalam media tersebut tidak terhubung dengan internet (disajikan secara offline) dengan alasan materi yang disajikan sudah kompilasi dari berbagai sumber belajar sehingga sudah cukup banyak dan tidak perlu di link dengan sumber dari internet secara online. Penyajian materi secara offline untuk menghindari dampak negatif situs porno dan untuk mempertahankan konsentrasi siswa dalam belajar (tidak browsing) situs internet lainnya. Materi pelajaran yang beredar di internet cukup luas dan belum sesuai dengan harapan guru serta tingkat keterbacaan siswa. Jika dilihat dari segi biaya, maka penggunaan internet dalam pembelajaran membutuhkan biaya yang cukup besar.

Media pembelajatan berbasis web terbukti dapat meningkatkan keterampilan berpikir kritis dan kemampuan kognitif siswa. Media pembelajaran berbasis web juga cocok untuk siswa berkemampuan akademik tinggi mapun siswa berkemampuan akademik rendah. Oleh karena itu, guru disarankan untuk mencoba merancang media pembelajaran berbasis web dengan menggunakan program web page maker untuk konsep lain maupun mata pelajaran yang lainnya. Secara global, diperlukan suatu kebijakan dari pimpinan (kepala sekolah) untuk mengembangkan media pembelajaran berbasis web secara terpadu untuk semua mata pelajaran yang nantinya dapat diintegrasikan di dalam website sekolah secara online sehingga dapat diakses siswa di rumah.

\section{Persepsi Siswa Kelas V SD Islam Sabilillah Malang terhadap Penerapan Media Pembelajaran Berbasis Web}

Secara umum, siswa kelas V SD Islam Sabilillah Malang merasa senang ketika mengikuti kegiatan pembelajaran dengan menggunakan media pembelajaran berbasis web. Berdasarkan analisis data, $80 \%$ siswa merasa mudah dalam mengoperasikan media pembelajaran berbasis web Siswa merasa mudah mengoperasikan karena mereka hanya dituntut dapat mengoperasikan komputer under windows khususnya program browsing (Mozilla Firefox, Internet Explorer, atau Opera). Berdasarkan analisis, 90\% siswa merasa mudah memahami materi dalam media pembelajaran berbasis web. Materi pembelajaran dalam media pembelajaran berbasis web disertai dengan ilustrasi gambar dan animasi sehingga memudahkan siswa dalam belajar. Mereka juga merasa mudah memahami konsep karena materi yang disajikan dalam media tersebut disusun oleh guru dengan menggunakan bahasa sehari-hari yang mudah dipahami oleh siswa.

Jika dilihat dari aspek kemenarikan, 86,7\% siswa merasa tertarik untuk mempelajari materi dalam media pembelajaran berbasis web. Ketertarikan siswa terhadap media pembelajaran berbasis web antara lain karena media tersebut dianggap baru, tampilan medianya menarik dengan animasi, ilustrasi yang dirancang sesuai dengan perkembangan anak SD. Latihan soal interaktif menarik perhatian siswa karena dilengkapi dengan arahan, kunci jawaban dan nilai akhir serta komentar jika siswa mengalami kesalahan atau pujian jika jawabannya benar. Berdasarkan analisis, 70\% siswa merasa penasaran dan ingin terus belajar dengan menggunakan media pembelajaran berbasis web.

Jika dilihat dari aspek kesenangan, (80\%) siswa merasa senang dan enjoy ketika menggunakan media pembelajaran berbasis web. Siswa merasa senang menggunakan media pembelajaran berbasis web karena media tersebut dirancang dengan berbagai animasi dan ilustrasi yang menarik serta interaktif. Siswa tidak merasa tertekan, mereka belajar santai tetapi serius. Motivasi siswa ketika belajar menggunakan media pembelajaran berbasis web cukup baik yaitu 66,7\%. Motivasi tersebut muncul karena pengalaman siswa selama mengikuti pembelajaran berbasis web dirasa menyenangkan. Faktor pendukung lain munculnya motivasi belajar siswa adalah sajian media yang menarik dan sesuai dengan dunia anak yaitu dunia bermain.

\section{SIMPULAN DAN SARAN}

\section{Simpulan}

Hasil penelitian menunjukkan bahwa ada pengaruh penerapan media pembelajaran berbasis web terhadap keterampilan berpikir kritis dan kemampuan kognitif. Jika dikaitkan dengan kemampuan akademik siswa, ada pengaruh kemampuan akademik terhadap keterampilan berpikir kritis dan kemampuan kognitif. Tidak ada pengaruh interaksi antara penerapan media pembelajaran berbasis web dengan kemampuan akademik terhadap keterampilan berpikir kritis dan kemampuan kognitif yang berarti bahwa tidak ada perbedaan 
keterampilan berpikir kritis dan kemampuan kognitif siswa yang berkemampuan akademik tinggi maupun siswa yang berkemampuan akademik rendah setelah menerapkan media pembelajaran berbasis web. Siswa kelas V SD Islam Sabilillah Malang merasa mudah dalam mengoperasikan media, merasa tertarik, dan merasa senang ketika mengikuti kegiatan pembelajaran dengan menggunakan media pembelajaran berbasis web.

\section{Saran}

Hasil penelitian menunjukkan bahwa media pembelajaran berbasis web efektif untuk meningkatkan keterampilan berpikir kritis dan kemampuan kognitif sehingga perlu dijadikan sebagai salah satu pertimbangan dalam memilih media pembelajaran berbasis komputer. Bagi peneliti lanjutan, hasil penelitian ini dapat dijadikan sebagai salah satu acuan dalam melakukan penelitian lanjutan atau penelitian pengembangan dengan cara mengintegrasikan media pembelajaran berbasis web dengan strategi pembelajaran kooperatif.

\section{DAFTAR RUJUKAN}

Arends, R. I. (2012). Learning to Teach Ninth Edition. New York: Mc Graw Hill Book Co.

Dabutar, J. (2007). Pengaruh Media Pembelajaran Terhadap Hasil Belajar Pengelasan Pada Siswa Yang Berprestasi Tinggi Dan Rendah Di Smk Swasta 1 Trisakti Laguboti-Kabupaten Toba Samosir. Digital Library Universitas Negeri Malang.

Febriyanti, A. (2007). Efektivitas pemanfaatan media komputer dalam pembelajaran IPA kelas Semester Genap Tahun Ajaran 2006/2007 di SDN Percobaan II Malang. Universitas Negeri Malang.

Gora, W. (2005). Membuat CD Multimedia Interaktif untuk Bahan Ajar E-Learning. jakarta: Elex Media Komputindo.

Hadi, S. (2007). Pengaruh Strategi Pembelajaran Cooperative Script terhadap Keterampilan Berpikir Kritis, Keterampilan Metakognitif, dan kemampuan Kognitif Biologi pada Siswa SMA Laboratorium Universitas Negeri Malang. Malang.

Hadi, S. (2009). Pengaruh penerapan strategi pembelajaran problem based learning (PBL) terhadap keterampilan metakognitif dan pemahaman konsep siswa kelas X di SMA Negeri 8 Malang pada kemampuan akademik berbeda. Universitas Negeri Malang.

Henry, S. (2006). Manajemen Sumber Daya Manusia. Yogyakarta: STIE YKPN.

Khosrow-Pour, M. (2001). Web-based instructional learning. IGI Global.

Krathwohl, D. R. (2002). A revision of Bloom's taxonomy: An overview. Theory into Practice, 41(4), $212-218$.

Kuswana, W. S. (2009). Pengembangan Perkuliahan E-learning Berbasis Web (Studi Kasus R and D di JPTM FPTK UPI).

Lieberman, A., \& Pointer Mace, D. (2010). Making practice public: Teacher learning in the 21st century. Journal of Teacher Education, 61(1-2), 77-88.

Mustafa, K. O. C. (2005). Individual learner differences in web-based learning environments: From cognitive, affective and social-cultural perspectives. Turkish Online Journal of Distance Education, 6(4), 12-22.

Nurmaliah, C. (2009). Keterampilan Berpikir Kritis, Metakognisi Dan Hasil Belajar Biologi Siswa SMP Negeri Di Kota Malang. Universitas Negeri Malang.

Sudaryanto, S. (2008). Kajian Kritis tentang Permasalahan Sekitar Pembelajaran.

Suparno, P. (2001). Teori perkembangan kognitif jean piaget. Kanisius.

Winarni, E. W. (2006). Pengaruh Strategi Pembelajaran Terhadap Pemahaman Konsep IPA-Biologi, Kemampuan Berpikir Kritis, dan Sikap Ilmiah Siswa Kelas V SD dengan Tingkat Kemampuan Akademik Berbeda di Kota Bengkulu. Disertasi Tidak Dipublikasikan. Malang: PPs Universitas Negeri Malang.

Wong, L. F., \& Trinidad, S. G. (2004). Using Web-based distance learning to reduce cultural distance. The Journal of Interactive Online Learning, 3(1), 1-13. 